\title{
STOSUNEK DO ŻYCIA LUDZKIEGO W PRAWIE KARNYM RZECZYPOSPOLITEJ SZLACHECKIEJ (STAN NORMATYWNY A PRAKTYKA)
}

\author{
„,...czlowiek nie zawsze byt pewny życia \\ w gronie szlachty-braci, nawet wśród sąsia- \\ dów i przyjaciót. Krew była goraca i tania, \\ przelewano ja przy byle sposobności"
}

Ten cytat zapożyczony ze świetnego dzieła Jana Stanisława Bystronia, doskonałego znawcy obyczajów w dawnej Polsce, znakomicie ilustruje, jak zasadniczo różnił się stosunek do życia ludzkiego w dawnej Polsce w porównaniu z dniem dzisiejszym. ${ }^{1}$ W Rzeczypospolitej szlacheckiej przestępstwa przeciwko życiu należały do poważnych, ale życie ludzkie nie było dobrem chronionym w sposób wyjątkowy, nie było nawet dobrem najwyższym, bo znacznie wyżej ceniono sobie w tych czasach cześć i honor, czy majątek niż życie człowieka. Konstatacja ta dotyczy w zasadzie wszystkich grup społecznych zamieszkujących polsko-litewskie państwo, niezależnie od przynależności stanowej, pozycji społecznej czy majątku. Takie traktowanie życia ludzkiego wynikało z wielu przyczyn: stosunków społecznych, kultury i obyczajów, a co najważniejsze - z realiów codziennej egzystencji każdego człowieka i wszystkich grup społecznych.

Otóż śmierć była obecna niemal codziennie i towarzyszyła ludziom od chwili narodzin aż po kres życia. Była więc zjawiskiem normalnym i oswojonym. Przede wszystkim dotykała dzieci - kobiety w tej epoce rodziły statystycznie rzecz ujmując, niezależnie czy była to chłopka czy królowa, kilkanaście razy, z czego wiek dorosły (znowu statystycznie) osiągało jeden, dwoje, najwyżej troje potomków. Śmiertelność w połogu była ogromna i stanowiła rzecz zwyczajną, choroby dzieci kończące się ich śmiercią także nie należały do rzadkości. To samo zresztą dotyczyło i dorosłych, zarazy występujące regularnie co kilka lat i klęski naturalne, zwłaszcza nie- 
urodzaj, w połączeniu z brakiem higieny i ówczesnym stylem życia także zbierały śmiertelne żniwo. Całość tych zjawisk w połączeniu z powszechnym przecież religijnym światopoglądem, który kazał godzić się z istniejącym w czasie życia ludzkiego stanem rzeczy uznając je tylko jako przystanek do życia wiecznego, determinowała tak indywidualny, jak i zbiorowy stosunek do egzystencji ludzkiej.

Stosunki społeczne, jak zawsze, znajdowały swoje odzwierciedlenie w prawie karnym. ${ }^{2} \mathrm{Z}$ jednej strony chroniło ono życie ludzkie w stopniu odzwierciedlającym świadomość społeczną, z drugiej strony jego opresyjność wyrażająca się w systemie surowych kar, z karą śmierci na czele, odpowiadała surowym warunkom życia i poglądom, że kary są konsekwencją nie tylko łamania praw ludzkich, ale przede wszystkim bożych i że ich surowość i publiczne wykonanie mają skuteczną moc odstraszającą. W rezultacie stosunek prawa karnego do życia ludzkiego odzwierciedlony w normach prawnych, a zwłaszcza w praktyce, był dość zagmatwany i niejednoznaczny. Przede wszystkim przestępstwa przeciwko życiu były zaliczane do przestępstw prywatnych, czasami zagrożonych karami publicznymi, czasami kompozycyjnym, a czasami wyłącznie prywatnymi. Rodzaj kary i jej wymiar zależał więc od wielu dodatkowych okoliczności, które musiał uwzględnić sąd. Zaliczano do nich winę, okoliczności i miejsce dokonania przestępstwa, stan społeczny, wiek, płeć sprawcy i ofiary oraz szereg jeszcze innych okoliczności wpływających na treść wyroku.

To samo zresztą dotyczy także przestępstw przeciwko zdrowiu, przez które rozumiano szeroko pojęte uszkodzenie ciała. Tu z kolei, w zależności od rodzaju i okoliczności popełnienia przestępstwa, uzależniano, czy w ogóle je zakwalifikować do kategorii przestępstw przeciwko zdrowiu, czy przeciwko czci ofiary.

Wiodącym systemem prawnym w badanym okresie było bez wątpienia prawo ziemskie. Do końca istnienia Rzeczypospolitej przestępstwa przeciwko życiu i zdrowiu były domeną prawa zwyczajowego (z wyjątkiem Litwy). Nie znaczy to, że brak było w tej dziedzinie uregulowań prawnych w ogóle, niektóre postacie tego przestępstwa były regulowane konstytucjami sejmowymi, ale rozwiązania te były fragmentaryczne i niepełne.

Prawo karne w dawnej Polsce cieszyło się zawsze dużym zainteresowaniem historyków, zwłaszcza specjalistów historii prawa, znaczące miejsce w badaniach zajmowała problematyka przedstawiana w niniejszej rozprawce. Zob. np. monografie: H. Grajewski, Kara śmierci w prawie polskim do połowy XIV wieku, Warszawa 1956; M. Handelsman, Kara w najdawniejszym prawie polskim, Warszawa 1908; idem, Prawo karne w Statutach Kazimierza Wielkiego, Warszawa 1909; D. Janicka, Prawo karne w trzech rewizjach prawa chełmińskiego, Toruń 1992; S. Kutrzeba, Mężobójstwo w prawie polskim XIV i XV w., Kraków 1907; idem, Dawne polskie prawo sądowe w zarysie, Lwów-Warszawa-Kraków 1927; R. Łaszewski, Wiejskie prawo karne w Polsce w XVII i XVIII wieku, Toruń 1988; W. Maisel, Poznańskie prawo karne do końca XVI wieku, Poznań 1963; idem, Archeologia prawna Polski, Warszawa-Poznań 1982; M. Mikołajczyk, Przestępstwo i kara w prawie miast Polski południowej XVI-XVIII wieku, Katowice 1998; J. Rafacz, Dawne polskie prawo karne, Warszawa 1932; R. Taubenschlag, Prawo karne polskiego średniowiecza, Lwów 1934; H. Zaremska, Niegodne rzemiosło. Kat w społeczeństwie Polski XIV-XVI w., Warszawa 1986. 
Prawo ziemskie wyróżniało dwie podstawowe postacie zabójstwa - zabójstwo umyślne, przy którym domniemano istnienie złego zamiaru i które traktowano jako kryminalne; ${ }^{3}$ mogło ono przybrać postać kwalifikowaną: ojcobójstwa, małżonkobójstwa, dzieciobójstwa i krewnobójstwa. ${ }^{4}$ Wspomniane wyżej konstytucje normowały jednak niektóre postacie mężobójstwa uznawane za umyślne. ${ }^{5}$ Dotyczyło to zabójstwa podczas napadu na dom szlachecki, na sejmiku, zabójstwa szlachcica przez plebeja, dokonanego na zgromadzeniu publicznym z rusznicy lub łuku. ${ }^{6}$ Pozostałe zabójstwa traktowano jako cywilne.

Zabójstwo umyślne karano ścięciem oraz kara główszczyzny; w stosunku do kwalifikowanych postaci zabójstwa, w braku rozwiązań ustawowych stosowano na zasadach analogii bądź prawo miejskie, bądź litewskie (kwalifikowane kary śmierci, konfiskata majątku, infamia - czasami łącznie). Zabójstwo cywilne karane było wieżą dolną w wymiarze 1 roku i 6 tygodni połączoną z zapłatą główszczyzny.

Główszczyzna i nawiązka jako kary prywatne mogły zostać przez uprawnionego w każdym konkretnym przypadku obniżone.

Wyjątkowym i znanym tylko prawu ziemskiemu był pojedynek - przestępstwo specyficzne znane tylko prawu ziemskiemu i skierowane zarówno przeciwko życiu, jak i zdrowiu. Tracił on jednak charakter przestępczy, jeżeli zgodę nań wyraził monarcha (zabójstwo lub zranienie w takiej sytuacji pociągało za sobą tylko zapłatę główszczyzny lub nawiązki). Konstytucja z 1588 r. wprowadzała karalność samego wyzwania na pojedynek (pół roku wieży górnej i 60 grzywien). Sama instytucja pojedynku była przez szlachtę w zasadzie potępiana, o ile był on kalkulowany z zimną krwią. ${ }^{7}$ Nie jest mi jednak znany żaden przypadek, w którym po niedozwolonym pojedynku sąd orzekł karę publiczną.

Szczególnie rozbudowane w prawie ziemskim były zranienia, które pociągały za sobą w zasadzie wyłącznie karę prywatną w postaci nawiązki. ${ }^{8}$

Samo ściganie tego przestępstwa ustawodawstwo traktowało ambiwalentnie; w latach 1493-1510 ścigał je starosta, w latach 1510-1538 - król, a na staroście i sądowych urzędnikach ziemskich spoczywał obowiązek zawiadomienia monarchy o takich przestępstwach popełnionych na terytorium, na którym sprawowali swój urząd; od 1539 - ponownie starosta, który od 1588 r. miał obowiązek ścigania sprawcy, gdy krewni ofiary nie wystąpili z pozwem przeciwko sprawcy w ciagu 1 roku; zob. J. Rafacz, Dawne polskie prawo karne, op. cit., s. 46.

$4 \quad$ W Koronie brakowało ustawowych przepisów dotyczących karania tego typu przestępstw (wyjątkiem było tu prawo chełmińskie, które w Prusach Królewskich stosowano wobec wszystkich mieszkańców oraz ekscepta mazowieckie). Sądy stosowały w takich przypadkach analogię odwołując się do prawa litewskiego lub chełmińskiego.

$5 \quad$ Uznanie tych przestępstw za umyślne nie wynikało jednak z faktu, że ochrona dotyczyła życia ludzkiego, ale uznano je za gwałty zagrażające porządkowi i bezpieczeństwu publicznemu.

6 I tu jednak sądy uwzględniały wiele instytucji prawa karnego albo wykluczające karalność danego czynu albo nawet wykluczające jego przestępność (np. afekt czy początek).

$7 \quad$ Tego typu pojedynki opinia szlachecka traktowała jako zabójstwo z premedytacją. Zauważył to już J.S. Bystroń, a potwierdzają ten fakt badania akt sądowych; zob. J.S. Bystroń, op. cit., s. 185-186; Z. Naworski, Szlachecki wymiar sprawiedliwości w Prusach Królewskich (1454-1772). Organizacja i funkcjonowanie, Toruń 2004, s. 133, 170.

$8 \quad$ Zob. J. Rafacz, Dawne polskie prawo..., op. cit., s. 187-189. 
Trzeba wyraźnie podkreślić, że zarówno mężobójstwa, jak i zranienia wśród szlachty były zjawiskiem bardzo częstym. Dokonywano ich jednak z reguły w okolicznościach, które powodowały, że prawie nigdy nie kwalifikowano ich jako przestępstw umyślnych. Występowały one bowiem jako zdarzenia towarzyszące wielu imprezom towarzyskim, zajazdom i awanturom, przy okazji pijaństwa, zwad i kłótni, o które nigdy nie było trudno. Tego typu wypadki dość rzadko trafiały przed oblicze ówczesnego szlacheckiego wymiaru sprawiedliwości. Załatwiano je z reguły polubownie na drodze ugody lub co najwyżej kierowano je do rozpatrzenia przez sądy polubowne (kompromisarskie). Nawet jeżeli trafiały one do sądów ziemskich lub grodzkich, kary w nich orzekane były najczęściej karami prywatnymi, czasami połączonymi z karami wieży dolnej lub częściej górnej.

Prawo karne było najlepiej rozwinięte i skodyfikowane w prawie miejskim, które zostało recypowane $\mathrm{z}$ krajów niemieckich i zachowało swój wyjątkowo surowy charakter. Dotyczyło to zarówno prawa magdeburskiego, jak i chełmińskiego. ${ }^{9}$ Dodać jednak trzeba, że ich modyfikacja dokonywana przez władze niemal każdego miasta i miasteczka, przy zachowaniu owego wspólnego pnia wywodzącego się z prawa sasko-magdeburskiego znacznie je zróżnicowała. Wynikało to zarówno $z$ recepcji najpierw wzorów rzymskich i włoskich, a potem ustawodawstwa europejskiego (zwłaszcza Caroliny) i dorobku ówczesnej europejskiej nauki, jak i dostosowania tego prawa do warunków miejscowych. Modyfikacje były też dokonywane na mocy przywilejów królewskich; już pod koniec XIII i w połowie XIV w. kilkanaście miast wielkopolskich i śląskich dzięki temu uzyskało prawo karania śmiercią schwytanych rabusiów i złoczyńców, złodziei, rozbójników, morderców, fałszerzy, świętokradców, gwałcicieli dziewic i mężatek. ${ }^{10}$ Skutkiem tego były daleko idące różnice między systemami prawa karnego poszczególnych ośrodków miejskich. Jednak dokonywane modyfikacje zawsze miały na celu prawnokarną ochronę ustalonego, a opartego na Dekalogu, systemu wartości i porządku uważanego za optymalny. ${ }^{11}$

Prawo miejskie w przedstawianym tu okresie do przestępstw przeciwko życiu i zdrowiu ludzkiemu zaliczało: zabójstwo, morderstwo, dzieciobójstwo, spędzenie płodu, porzucenie dziecka oraz uszkodzenie ciała.

Zabójstwo było umyślnym pozbawieniem życia, natomiast morderstwo było umyślnym i zuchwałym pozbawieniem życia dokonanym na drodze publicznej lub

Zob. B. Groicki, Artykuły prawa magdeburskiego. Postępek sądów około karania na gardle. Ustawa płacej u sądów, Warszawa 1954, s. 39-41, 191-192, 200; idem, Porządek sądów i spraw miejskich prawa majdeburskiego w Koronie Polskiej, Warszawa 1953, s. 209-215. Z kolei analiza prawa chełmińskiego została oparta na trzech rewizjach tego prawa $z$ lat 1566,1580 i 1594 . Żaden z tych projektów ostatecznie nie wszedł w życie, ale stanowią one wyraźną wskazówkę, jak prawo chełmińskie było stosowane w XVI w. w praktyce sądowej. Monografie poświęconą tej problematyce opracowała D. Janicka, Prawo karne..., op. cit. 
Stosunek do życia ludzkiego w prawie karnym Rzeczypospolitej szlacheckiej...

w domu ofiary. Trucicielstwo, zabójstwo za pomocą czarów, dzieciobójstwo oraz spędzenie płodu prawo uważało za szczególne formy tego przestępstwa (w zależności od sytuacji bądź jako kwalifikowane, bądź uprzywilejowane jego postacie). Z kolei zabójstwa nieumyślnego można było dokonać z niedbalstwa, nieostrożności lub przypadkiem; do tego typu zabójstwa zaliczono też zabójstwo w stanie nietrzeźwym lub z lekkomyślności.

Przestępstwem przeciwko zdrowiu było uszkodzenie ciała. Szczegółowe postacie tego przestępstwa były z reguły regulowane kazuistycznie, a szczegółowe rozwiązania nieraz znacząco się różniły. Np. w każdej z trzech kodyfikacji prawa chełmińskiego było ono uregulowane nieco odmiennie i obejmowało szereg postaci. Było to ciężkie uszkodzenie ciała (rana ciężka krwawa, ochromienie), krwawe okaleczenie (rany proste i krwawe), lekkie uszkodzenie ciała (wybicie zęba, poszarpanie ciała) i uderzenie (rany sine). Daleko posunięta kazuistyka normująca uszkodzenie ciała w kilkunastu szczegółowych artykułach, w ostatnim projekcie uwzględniała tylko zranienie na drodze publicznej i zranienie wzajemne w czasie bójki. Stopień uszkodzenia ciała i rodzaj ran stały się okolicznościami mającymi wpływ na rodzaj i wymiar kary. Rany sine (uderzenia) uznane zostały za przestępstwo czynnej zniewagi.

Karą za zabójstwo było ścięcie. Istniała jednak możliwość wykupienia się od kary śmierci za zabójstwo przez zapłatę główszczyzny, czyli kary prywatnej. Karę główszczyzny stosowano zawsze w wypadku zabójstwa nieumyślnego. Natomiast w przypadku zabójstwa umyślnego przepisy poszczególnych miasta były niekonsekwentne, zarówno umożliwiając zamianę kary śmierci na główszczyznę (wergeld), jak i ją wykluczając. To samo dotyczyło zabójstwa z przypadku, sądy orzekały główczyznę, ale gdy śmierć nastąpiła w sytuacji polowania na ptaki, ścinki drzew lub wyładowywania wozu, uwalniały od kary. Zabójstwo w stanie nietrzeźwym (ale nie dotyczyło to rozmyślnego upicia się) lub z lekkomyślności stanowiło podstawę złagodzenia kary i orzeczenia zamiast kary śmierci kary arbitralnej - główszczyzny, więzienia lub wydalenia z miasta.

Śmierć przez ścięcie była też stosowana do pozostałych postaci zabójstwa, w tym za trucicielstwo i spędzenie płodu; gdy spędzony płód już nie żył orzekano karę wydalenia z miasta.

Karą za morderstwo była śmierć przez łamanie kołem, podobnie jak za dzieciobójstwo, choć za dzieciobójstwo alternatywnie można było orzec karę pogrzebania żywcem (w praktyce za to przestępstwo sądy karały ścięciem). Ścięciem kończyło się zabójstwo dziecka przez jego porzucenie - jeżeli dziecku udało się przeżyć, sprawcy groziła kara arbitralna. 
Usiłowanie było traktowane tak jak dokonanie przestępstwa. Również współsprawcy, podżegacze i pomocnicy ponosili odpowiedzialność akcesoryjną w stosunku do odpowiedzialności sprawcy głównego zabójstwa lub morderstwa.

Nieletni wiek sprawcy uwalniał go od kary śmierci, jego opiekunowie mieli jednak obowiązek zapłacenia główszczyzny.

Obrona konieczna wyłączała bezprawność czynu, bezkarnym było też zabicie proskrybowanego lub schwytanego na gorącym uczynku gwałciciela lub cudzołożnika (gdy zabójcą był mąż lub ojciec kobiety).

Uszkodzenie ciała skutkowało orzeczeniem kar kompozycyjnych. Za rany ciężkie sprawca tracił rękę lub uiścić musiał nawiązkę w wysokości całej główszczyzny lub jej połowy, połowę główszczyzny sprawca płacił za ochromienie - za pozostałe rany trzeba było płacić nawiązkę, za spowodowanie kilku ran nawiązki kumulowały się, chyba że owe rany powstały w wyniku jednego uderzenia i w bliskiej od siebie odległości. Późniejsze rewizje zaostrzały karalność uszkodzenia ciała włączając je do systemu kar publicznych. Zranienie przy użyciu niebezpiecznej broni palnej lub siecznej, które pozostawiło wyraźną szpecącą dużą bliznę było karane śmiercią, kara ta lub ucięcie ręki groziła za zranienie ciężkie. Umyślne spowodowanie tego typu ran wykluczało możliwość wykupienia się od kary śmierci lub mutylacyjnej. Pozostałe rany pociągały za sobą kary nawiązki.

Karę nawiązki wynoszącą połowę główszczyzny płacili też podżegacze i pomocnicy.

Praktyka dotycząca przestępczości kryminalnej w miastach polskich wykazuje, że przestępstwa przeciwko życiu i zdrowiu człowieka zdarzały się relatywnie rzadko i stanowiły $10 \%-15 \%$ ogólnej liczby poważniejszych przestępstw, a przy uwzględnieniu także przestępstw drobnych masowo napływających do sądów miejskich (kłótnie, awantury, niesnaski i kłótnie rodzinne oraz sąsiedzkie, różne postacie kalumni itp.) ich liczba nie przekraczała kilku procent. ${ }^{12}$

12 M. Kamler, Kary za przestępstwa pospolite w dużych miastach Polski w drugiej połowie XVI i pierwszej połowie XVII wieku, „Kwartalnik Historyczny” 1994, R. 101, z. 3, s. 28-31, tabele 1-2; idem, Struktura i liczebność środowisk przestępczych Poznania i Krakowa w drugiej połowie XVI w., „Przeszłość Demograficzna Polski” 1984, t. 15, s. 76-79.; M. Mikołajczyk, Przestępstwo i kara w prawie miast Polski południowej XVI-XVIII wieku, op. cit., s. 35. W moich badaniach dotyczących przestępczości w Kowalewie Pomorskim znalazłem tylko 1 taką sprawę w ciągu 50 lat. W marcu 1685 r. toczył się proces przeciwko Mariannie Polaczkównie o dzieciobójstwo. Oskarżona przyznała jako się na karcie, która między cofessata schowana, że bez litości płód swój siekierą w szyjkę ciąwszy zabiła, a zwłoki schowała do skojca gdzie gęsi siadają. Sąd skazał oskarżoną aby na granicy [miasta ZN] żywo w dole było zakopana a palem przebita. Jednak na skutek interwencji wojewody chełmińskiego, starosty Kowalewa sąd niniejszy zważywszy, wolę sobie Jaśnie Wielmożnego siła ważąc... mieczem ściąć pozwala. Egzekucji dokonał Michał - kat toruński, a do obserwowania jej przebiegu sąd delegował dwóch ławników, którzy mieli ją pisarzowi sądowemu potwierdzić. Po ścięciu skazaną miano pochować na miejscu egzekucji to iest za szpitalikiem, do tego jednak akurat nie doszło, bo ciało zabrał proboszcz i pogrzebał przy kościele; Archiwum Państwowe w Toruniu, Akta miasta Kowalewa, sygn. XV-30, k. 25v-29. 
Stosunek do życia ludzkiego w prawie karnym Rzeczypospolitej szlacheckiej...

Wiejskie prawo karne do przestępstw przeciwko życiu i zdrowiu zaliczało: zabójstwo, samobójstwo, zranienie, pobicie i bójki.

Zabójstwo podobnie w prawie ziemskim, jak i miejskim dzielono na umyślne i nieumyślne.

Kwalifikowanymi postaciami zabójstwa było zabójstwo krewnych i powinowatych, do dzieciobójstwa zaliczano też przestępstwo spędzenia płodu. Sprawy te traktowano jako przestępstwa prywatne i ścigano je na podstawie skargi rodziny ofiary. W wypadku rozpatrywania tych przestępstw przez sady wiejskie z reguły sprawa kończyła się ugodą i wypłatą główszczyzny, często też sądy nakładały na sprawcę przestępstwa kary dodatkowe w postaci plag, kary więzienia i pokuty. Najbardziej bulwersujące postacie zabójstwa, za zgodą władz dominialnych, kierowano do sądów najbliższego miasteczka, czasami trafiały one przed sąd wiejski lub pana dominialnego, kiedy orzekały one karę śmierci, do jej wykonania wzywano kata z najbliższego miasta. Generalnie trzeba jednak stwierdzić, że nawet i w takim przypadku do wykonania wyroku nie dochodziło, łaskę bowiem skazanemu przestępcy okazywała władza dominialna.

Przestępstwem występującym wyłącznie w prawie wiejskim, aczkolwiek niezwykle rzadko, było samobójstwo. ${ }^{13}$ Zaliczano je jednak nie tyle do przestępstw przeciwko życiu, ile do przestępstw religijnych i takież kary orzekano (zakaz pochowania ciała w poświęconej ziemi, spalenie zwłok, plagi i pokuta, o ile niedoszły samobójca nie umarł).

Zranienie i pobicie było rozpatrywane przez sądy wiejskie niechętnie, z reguły występowało tu pozasądowe jednanie, a często takie jednanie nakazywały także sądy, o ile sprawa trafiała na wokandę. Jeżeli sądy w tych sprawach wydawały wyroki, to ograniczały się one często do orzeczenia wysokości zadośćuczynienia i nie nakładały na sprawców żadnej kary. Równie często poza orzeczeniem nawiązki sądy stosowały kary arbitralne (kary pieniężne na rzecz pana, sądu, kościoła, plagi i z reguły - przeprosiny).

Podobnie wiejski wymiar sprawiedliwości traktował bójki, choć te traktowano jako przestępstwa publiczne i stąd ugody występowały bardzo rzadko. Z reguły sądy orzekały zadośćuczynienie, pokrycie kosztów leczenia i innych szkód, plagi oraz różne formy ograniczenia wolności - najczęściej gąsior. ${ }^{14}$

\footnotetext{
13 Tezę o traktowaniu samobójstwa jako przestępstwa występującego w prawie miejskim stawia M. Mikołajczyk, choć sam podkreśla, że jest ona kontrowersyjna; zob. M. Mikołajczyk, Przestępstwa przeciwko życiu w małych miastach polskich (na przykładzie Żywca i Miechowa) XVI-XVIII wieku, [w:] Państwo - prawo - sprawiedliwość. Dawniej i dziś, A. Lityński (red.), Katowice 1993, s. 80-83.

Zob. R. Łaszewski, Wiejskie prawo karne w Polsce w XVII i XVIII wieku, op. cit., s. 70-85.
} 
Drugim aspektem związanym z omawianą problematyką jest stosunek społeczeństwa, a w konsekwencji i prawa karnego, do kary śmierci. ${ }^{15}$ Tu poglądy społeczne były jednoznaczne. Kara śmierci była uznawana za karę podstawową i powszechnie akceptowaną. Co więcej, okrutne i publiczne sposoby jej wykonywania były uznawane za najlepszy środek prewencji generalnej, stąd wiele miast nakazywało obligatoryjne uczestnictwo w jej wykonaniu mieszkańcom miasta z dziećmi włącznie. Ponadto eliminowała ona definitywnie przestępcę, uwolnienie od niej w ówczesnych warunkach oznaczało brak nad nim późniejszej kontroli, no i była dużo tańsza niż kara więzienia. Kara miała charakter formalny i musiała być wykonana. Jeżeli skazaniec przed wykonaniem wyroku zmarł, karano zwłoki.

Kary śmierci dzielono na zwyczajne, do których zaliczano ścięcie, powieszenie i utopienie, a w prawie wojskowym - rozstrzelanie oraz na kwalifikowane, czyli ćwiartowanie żywcem, spalenie na stosie, wbicie na pal czy zakopanie żywcem. Były to zresztą kary tzw. pojedyncze, które w sumie i tak były łagodniejsze w stosunku do kar złożonych, polegających na szczególnym udręczeniu skazańca przed samą egzekucją. Były to: pochód hańbiący, kiedy prowadzony na miejsce stracenia skazaniec był szarpany kleszczami, darto z niego pasy, obcinano ręce itp.; przed spaleniem żywcem czy powieszeniem skazańca najpierw piętnowano, obcinano język, najpierw palono ręce itp.; łamanie kołem, wplecenie skazańca w koło i wystawienie koła na palu, utopienie żywcem w zaszytym razem z rozmaitymi zwierzętami worku (najczęściej kotami lub szczurami) itp. Bardzo mocno trzeba przy tej okazji podkreślić, że tak dalekie zróżnicowanie okrutnych kar kończących się śmiercią skazańca nie wynikało wcale z obowiązującego wówczas prawa pisanego. Prawo chełmińskie znało tylko pięć takich kar: ścięcie mieczem, powieszenie, łamanie kołem, spalenie żywcem i pogrzebanie żywcem, podobnie kary wyglądały u Groickiego. Carolina dodała jeszcze utopienie i ćwiartowanie. ${ }^{16}$ Znacznie bogatszy katalog kar, tak plastycznie opisywanych przez Bystronia, to już inicjatywa samych sądów i wyobraźni sędziów, akceptowana zresztą przez władze i społeczeństwo. ${ }^{17}$

Kary tego typu wykonywano w całej Rzeczypospolitej, przy czym w określaniu sposobu wykonania kary śmierci kwalifikowanej sędziowie mieli pełną swobodę modyfikowania przepisów prawnych wedle swego uznania.

\footnotetext{
15 Znawcy obyczajów omawianej epoki surowość ówczesnych praw wiążą z nikłą wrażliwością moralną i fizyczną na kary cielesne stosowane wówczas powszechnie i będące podstawowym elementem wychowania, a także z brutalnością ówczesnych obyczajów wynikającą z nękających ówczesne społeczeństwo schorzeń i zboczeń, z drastycznym okrucieństwem i sadyzmem na czele; zob. Z. Kuchowicz, Obyczaje staropolskie w XVII-XVIII wieku, Łódź 1975, s. 545-570.

16 Zob. D. Janicka, Prawo karne..., op. cit., s. 50.

17 J.S. Bystroń, Dzieje obyczajów..., op. cit., t. II, s. 318-326.
} 
Kwestie tu wskazane pozostają poza dyskusją, powstaje natomiast pytanie, jak masowe było to zjawisko i czy rzeczywiście kary śmierci były tak często wykonywane, jak je orzekano i jak kara ta była traktowana przez różne systemy prawne.

Odpowiedź na to ostatnie pytanie jest stosunkowo prosta. Kary śmierci, zwłaszcza w postaci kwalifikowanej, były orzekane i wykonywane najczęściej w miastach. W prawie ziemskim ich znaczenie było znacznie mniejsze i orzekały je wyłącznie sądy grodzkie (głównie jednak wobec plebejów), ${ }^{18} \mathrm{~W}$ prawie wiejskim były one stosowane wyjątkowo. Ale i prawo miejskie nie było w tej materii jednolite. Po pierwsze paradoksem wydaje się konstatacja, że korzystanie z kary śmierci najczęściej występowało w Polsce południowej, w Prusach Królewskich i w Wielkopolsce, gdzie mieszkało przecież więcej Niemców i gdzie recepcja prawa niemieckiego była najpełniejsza zjawisko to występowało relatywnie rzadziej. Po drugie spornym jest, czy bardziej surowe orzecznictwo charakteryzowało wielkie miasta, czy małe miasteczka. ${ }^{19} \mathrm{~W}$ odniesieniu do praktyki miejskiego wymiaru sprawiedliwości sprawa wydaje się znacznie bardziej skomplikowana. Orzekanie kary śmierci we wszystkich jej postaciach charakteryzowało znaczące zróżnicowanie bez względu na wielkość miasta, aczkolwiek w miasteczkach małych owo zróżnicowanie było znacznie większe niż w miastach dużych. Badania M. Mikołajczyka wskazują na bardzo znaczące różnice w orzekaniu kar śmierci przez sądy małych miast, a jednocześnie na znaczące różnice dotyczące orzekania kar śmierci w Krakowie w różnych okresach. $^{20}$

I tak jednak zjawisko to wydaje się przerażające. W sądach miejskich wyroki śmierci stanowiły ok. 40\% wszystkich wydanych wyroków. Oczywiście dane te są wyjątkowo nieprecyzyjne, tak ze względu na podkreślany już partykularyzm poszczególnych miast, jak i fakt, że orzekanie kary śmierci z biegiem czasu charakteryzowało się tendencją malejącą.

Wydaje się jednak, że samo orzekanie kary śmierci nie oznaczało jeszcze jej wykonania. Podstawowym hamulcem związanym z wykonywaniem kar śmierci (a także stosowaniem w postępowaniu sądowym tortur) były koszty. Co prawda, obciążały one powoda, ale nie zawsze był on w stanie je pokryć i wtedy spadały na miasto. Było to i tak tańsze od więzienia, ale przecież w większości miast więzień (w dzisiejszym rozumieniu tego słowa) w ogóle nie było i chyba jeszcze wtedy nie wyobrażano sobie możliwości ich istnienia. Zdarzało się więc, że skazaniec w takiej sytuacji unikał kary. Utrzymanie kata, zwłaszcza o wysokich kwalifika-

\footnotetext{
18 Między poszczególnymi sądami grodzkimi także występowały drastyczne czasami różnice w liczbie orzekanych wyroków śmierci. Wystarczy porównać krakowski sąd grodzki, w którym rocznie skazywano na karę śmierci kilka osób z sądem grodzkim malborskim, gdzie tego typu wyroki były zupełnie wyjątkowe.

19 To pierwsze stanowisko prezentował B. Baranowski, to drugie - J. Rafacz, zob. B. Baranowski, Życie codzienne małego miasteczka w XVII i XVIII wieku, Warszawa 1975, s. 47; J. Rafacz, Sprawy karne w sądach miejskich w epoce nowożytnej, „Kwartalnik Historyczny” 1933, R. XLVII, t. I, z. 4, s. 559-560. 
cjach było kosztowne i mogły sobie na to pozwolić tylko bogate miasta. Zauważmy, że w 1510 r. na całym Mazowszu miasta zostały podzielone na 3 grupy, z których każda miała utrzymać jednego kata, a Warszawa otrzymywała na utrzymanie kata dotacje z urzędu marszałkowskiego. ${ }^{21}$ Stąd także niechęć do korzystania z kata przez społeczności wiejskie. Ponadto prawo (i zwyczaj) wypracowały szereg instytucji umożliwiających przestępcy uniknięcie najcięższej kary. Przede wszystkim dość szeroko stosowano darowanie kary, które było formą dzisiejszego ułaskawienia. Darować karę mógł sejm, król, mogli sędziowie we własnych sądach z inicjatywy własnej lub w wyniku nieformalnej protekcji, mógł wreszcie karę darować powód. Można było też karę wyprosić, wcale często zdarzały się wypadki, kiedy to zarówno mężczyznę, jak i kobietę można było uwolnić, poprzez natychmiastowe poślubienie skazańca, mógł też skazańca uwolnić od kary kat.

Reasumując. Nie sposób z dzisiejszej perspektywy pozytywnie ocenić stosunek do życia i zdrowia ludzkiego w tamtej epoce. Tym niemniej trzeba wyraźnie podkreślić, że na tle ówczesnej Europy tak prawo polskie, jak i praktyka wymiaru sprawiedliwości wydają się mniej okrutne i bardziej humanitarne niż systemy prawne większości państw. Dotyczy to zwłaszcza praktyki - od orzeczenia kary śmierci do jej wykonania na ziemiach polskich było jednak bardzo daleko. Jednocześnie na tle niniejszych rozważań wydaje się wyjątkowo potrzebne opracowanie syntezy dotyczącej omawianej tu problematyki, tym bardziej, że obecny stan badań taką syntezę w pełni umożliwia.

\section{BIBLIOGRAFIA}

1. Baranowski B., Życie codzienne małego miasteczka w XVII i XVIII wieku, Warszawa 1975.

2. Bystroń J.S., Dzieje obyczajów w dawnej Polsce. Wiek XVI—XVIII, t. II, Warszawa 1994.

3. Grajewski H., Kara śmierci w prawie polskim do połowy XIV wieku, Warszawa 1956.

4. Groicki B., Artykuły prawa magdeburskiego. Postępek sądów około karania na gardle. Ustawa o płacej sądów, Warszawa 1954.

5. Groicki B., Porządek sądów i spraw miejskich prawa majdeburskiego w Koronie Polskiej, Warszawa 1953.

6. Handelsman M., Kara w najdawniejszym prawie polskim, Warszawa 1908.

7. Handelsman M., Prawo karne w Statutach Kazimierza Wielkiego, Warszawa 1909.

8. Janicka D., Prawo karne w trzech rewizjach prawa chełmińskiego z XVI wieku, Torun 1992.

21 Por. H. Zaremska, Niegodne rzemiosło..., op. cit., s. 29-31. Cytowana autorka podkreśla też, że w XVI w. niewiele miast miało własnych katów. W Wielkopolsce były to zaledwie 3 miasta, w Małopolsce - 5, na Mazowszu - 6 . Trudności z pozyskaniem kata wiązały się przecież nie tylko z kosztami jego utrzymania, ale przede wszystkim z pozycją społeczną tego zawodu - był to wszakże urząd hańbiący. Wreszcie, pamiętać należy, że katowska profesja wymagała także określonych zawodowych umiejętności, których trzeba było się gdzieś nauczyć. H. Zaremska tę ostatnią kwestię porusza tylko marginalnie. 
9. Kamler M., Kary za przestępstwa pospolite w dużych miastach Polski w drugiej połowie XVI i pierwszej połowie XVII wieku, „Kwartalnik Historyczny” 1994, R. 101, z. 3.

10. Kamler M., Struktura i liczebność środowisk przestępczych Poznania i Krakowa w drugiej połowie XVI w., „Przeszłość Demograficzna Polski” 1984, t. 15.

11. Kuchowicz Z., Obyczaje staropolskie w XVII-XVIII wieku, Łódź 1975.

12. Kutrzeba S., Dawne polskie prawo sądowe w zarysie, Lwów-Warszawa-Kraków 1927.

13. Kutrzeba S., Mężobójstwo w prawie polskim XIV i XV w., Kraków 1907.

14. Łaszewski R., Wiejskie prawo karne w Polsce w XVII i XVIII wieku, Toruń 1988.

15. Maisel W., Archeologia prawna Polski, Warszawa-Poznań 1982.

16. Maisel W., Poznańskie prawo karne do końca XVI wieku, Poznań 1963.

17. Mikołajczyk M., Przestępstwo i kara w prawie miast Polski południowej XVI-XVIII wieku, Katowice 1998.

18. Naworski Z., Szlachecki wymiar sprawiedliwości w Prusach Królewskich (1454-1772). Organizacja i funkcjonowanie, Toruń 2004.

19. Rafach J., Sprawy karne w sądach miejskich w epoce nowożytnej, „Kwartalnik Historyczny” 1933, R. XLVII, t. I, z. 4.

20. Rafacz J., Dawne polskie prawo karne, Warszawa 1932.

21. Taubenschlag R., Prawo karne polskiego średniowiecza, Lwów 1934.

22. Zaremska H., Niegodne rzemiosło. Kat w społeczeństwie Polski XIV-XVI w., Warszawa 1986. 


\section{THE ATTITUDE TO A HUMAN LIFE IN THE CRIMINAL LAW \\ OF THE POLISH-LITHUANIAN COMMONWEALTH \\ (LEGAL STATUS AND PRACTICE)}

The present article is devoted to two points. First - the security of a human life and health in old polish criminal law (noble, urban, and rural). Second the issue of the death penalty in the entire system of penalties, frequency of its adjudication in courts and the ways of its execution. This article presents only the most important issues, in both existing legislation, as well as the practice.

Key words: human life, system of penalties, criminal law, execution 